\title{
Sensitive and rapid detection of Vero toxin-producing Escherichia coli using loop-mediated isothermal amplification
}

\author{
Yukiko Hara-Kudo, ${ }^{1}$ Jiro Nemoto, ${ }^{2}$ Kayoko Ohtsuka, ${ }^{3}$ Yuko Segawa, ${ }^{1}$ \\ Kosuke Takatori, ${ }^{1}$ Tadashi Kojima ${ }^{2}$ and Masanari Ikedo ${ }^{2}$ \\ ${ }^{1}$ Division of Microbiology, National Institute of Health Sciences, 1-18-1 Kamiyoga, Setagaya-ku, \\ Tokyo 158-8501, Japan \\ ${ }^{2}$ Eiken Chemical Co. Ltd, 143 Nogi Nogimachi, Shimotsuga-gun, Tochigi 329-0114, Japan \\ ${ }^{3}$ Saitama Institute of Public Health, Saitama 338-0824, Japan
}

Correspondence

Yukiko Hara-Kudo

ykudo@nihs.go.jp

Received 6 July 2006

Accepted 25 October 2006

\begin{abstract}
A loop-mediated isothermal amplification (LAMP) assay was developed to detect Vero toxin (VT)-producing Escherichia coli rapidly (within $60 \mathrm{~min}$ ). The 24 strains of VT-producing E. coli were successfully amplified, but 6 strains of non-VT-producing E. coli and 46 bacterial species other than E. coli were not. The sensitivity of the LAMP assay was found to be $>0.7$ c.f.u. per test using serogroups $\mathrm{O} 157, \mathrm{O} 26$ and $\mathrm{O} 111$ of VT-producing $E$. coli; this sensitivity is greater than that obtained by PCR assay. Furthermore, the LAMP assay was examined for its ability to detect VT-producing $E$. coli in food because of the difficulty of detection in food samples. The recovery of VT-producing $E$. coli by LAMP assay from beef and radish sprouts inoculated with the pathogen was high, similar to that obtained using culture methods with direct plating and/or plating after immunomagnetic separation. Although PCR assay was unable to recover VT-producing E. coli from half of the radish samples, LAMP assay was successful in most samples. In addition,

VT-producing E. coli was successfully detected in cultures of the beef samples by LAMP assay, but not by the culture method. The LAMP products in naturally contaminated beef samples were analysed to confirm the specific amplification of the VT-encoding gene, and were found to show a specific ladder band pattern on agarose gel after electrophoresis. Additionally the sequences of the LAMP products coincided well with the expected sequences of the VT-encoding gene. These results indicate that the proposed LAMP assay is a rapid, specific and sensitive method of detecting the VT-producing E. coli.
\end{abstract}

\section{INTRODUCTION}

Sensitive and rapid detection methods for Vero toxin (VT)producing Escherichia coli are required. VT-producing E. coli has many serotypes, although $\mathrm{O} 157$ predominates. Thus, the early detection of VT is important to save both time and cost. The present culture methods require more than 3 days, and rapid detection methods like enzyme immunoassay require a high population of the target pathogen (Bennett et al., 1996; Chapman et al., 2001). A PCR assay was developed to rapidly detect target pathogens in enrichment cultures; however, the assay generally requires electrophoresis to detect the amplicon, which takes several hours. Recently, real-time PCR assays have been applied to detect food-borne pathogens, but such assays requires an expensive thermal cycler with a fluorescence detector (Mullah et al., 1998).

Abbreviations: IMS, immunomagnetic separation; LAMP, loop-mediated isothermal amplification; VT, Vero toxin.
Loop-mediated isothermal amplification (LAMP) is a novel nucleic acid amplification method that relies on an autocycling strand displacement DNA synthesis performed by the Bst DNA polymerase large fragment (Nagamine et al., 2001, 2002; Notomi et al., 2000). LAMP is different from PCR in that four or six primers perform the amplification of the target gene, the amplification uses a single temperature step at $60-65^{\circ} \mathrm{C}$ for about $60 \mathrm{~min}$, and the amplification products have many types of structures in large amounts. Thus, LAMP is faster and easier to perform than PCR, as well as being more specific. Furthermore, gel electrophoresis is not needed, because the LAMP products can be detected indirectly by the turbidity that arises due a large amount of by-product, pyrophosphate ion, being produced, yielding an insoluble white precipitate of magnesium pyrophosphate in the reaction mixture (Mori et al., 2001). Since the increase in the turbidity of the reaction mixture according to the production of precipitate correlates with the amount of DNA synthesized, real-time monitoring of the LAMP reaction can be achieved by real-time measurement of turbidity. 
VT is classified into two types: VT1 and VT2 (Jackson et al., 1987), and VT1- and VT2-producing E. coli are regarded as pathogens. VT1 is identical with Shiga toxin. VT2 differs from VT1 in its physico-chemical, immunological and molecular genetic properties. Several variants of VT, especially VT2, have been reported. Sensitive detection methods for VT must target VT1 and VT2, including VT2vha, VT2vhb (Ito et al., 1990, 1991) and VT2vp1 (Lin et al., 1993; Weinstein et al., 1988). In the present study, we developed a LAMP assay to detect VT1 and/or VT2producing E. coli rapidly and sensitively.

\section{METHODS}

Bacterial strains. Is this present study, 24 strains of VT-producing E. coli, 6 strains of non-VT-producing E. coli and 46 bacterial species other than E. coli (Table 1) were tested using the LAMP assay to show specificity. Vibrio spp. were cultured on trypticase soy agar (TSA) medium (Difco) containing $3 \% \mathrm{NaCl}$ for $18 \mathrm{~h}$ at $37^{\circ} \mathrm{C}$. The other bacteria were cultured on brain heart infusion agar (Difco) at $37^{\circ} \mathrm{C}$ for $18 \mathrm{~h}$. Colonies were suspended to $2 \mathrm{McF}$ arland standard turbidity in $5 \mathrm{ml}$ PBS. The bacterial suspension was diluted in PBS to $10^{6}$ c.f.u. $\mathrm{ml}^{-1}$. The dilutions were used for the LAMP assay.

Cultures of five strains of VT-producing E. coli (nos. 157-891, ATCC43890, 157-120, BFR 26015 and 97353) were tested to investigate the sensitivity of the LAMP and PCR assays. They were cultured in tryptic soy broth (TSB; Difco) at $37^{\circ} \mathrm{C}$ for $18 \mathrm{~h}$ and serially diluted tenfold in PBS to $10^{-3}-10^{-7}$ dilutions. Each dilution was used for both LAMP and PCR assays. To determine the inoculum size, $0.1 \mathrm{ml}$ each dilution of VT-producing E. coli culture was plated onto TSA in duplicate. After incubation at $37^{\circ} \mathrm{C}$ for $18 \mathrm{~h}$, the number of colonies was counted.

Food samples. Ground beef and radish sprouts were purchased from retail shops in Tokyo for inoculation with VT-producing $E$. coli. The aerobic bacterial counts in the ground beef and radish sprouts were 5.3 and $8.2 \log$ c.f.u. $\mathrm{g}^{-1}$, respectively.

LAMP assay. In the present study, five primers (two inner primers, two outer primers and one loop primer) targeting the VT1 gene and six primers (two inner primers, two outer primers and two loop primers) targeting the genes of VT2, VT2vha, VT2vhb and VT2vp1 (Table 2) were used for the LAMP reactions (Notomi et al., 2000); the domains targeted by these primers are shown in Fig. 1. The LAMP reaction was performed using a Loopamp DNA amplification kit (Eiken Chemical). Each $50 \mu$ l bacterial dilution or culture sample was added to $42 \mu \mathrm{l}$ extraction solution $(50 \mathrm{mM} \mathrm{NaOH}, \mathrm{pH} 12.5$ ) (Beige et al., 1995) in order to extract DNA before heating at $100^{\circ} \mathrm{C}$ for $5 \mathrm{~min}$. After flash heating, the samples were added to $8 \mu \mathrm{l} \mathrm{M}$ Tris/ $\mathrm{HCl}(\mathrm{pH} \mathrm{7.0)}$ and centrifuged (Tomy) at $2000 \mathrm{~g}$, and the supernatant was transferred to a new micro-tube and used as the template DNA solution for the LAMP assay. The LAMP reaction mixture contained the primers for VT detection $(20 \mu \mathrm{l})$, Bst polymerase $(1 \mu \mathrm{l})$ and template DNA solution $(5 \mu \mathrm{l})$. The reaction components were mixed in a tube, incubated at $65^{\circ} \mathrm{C}$ for $60 \mathrm{~min}$ using a Loopamp LA-200 (Teramecs) and then heated to $80^{\circ} \mathrm{C}$ for $2 \mathrm{~min}$ to terminate the reaction. LAMP amplification was detected as a value of turbidity at $650 \mathrm{~nm}$ using a Loopamp LA-200 in real-time. In addition, turbidity produced by the by-product magnesium pyrophosphate was noted visually. VT-producing E. coli DNA extracted from a suspension of the pathogen by heating at $95^{\circ} \mathrm{C}$ for $10 \mathrm{~min}$ was used as a positive control each time.
Aliquots of $1 \mu \mathrm{L}$ LAMP products were electrophoresed in $2 \%$ agarose gel. After staining with ethidium bromide, the products were detected under UV light.

PCR assay. The bacterial dilutions in PBS of five strains of VTproducing E. coli, described above, were heated at $95^{\circ} \mathrm{C}$ for $10 \mathrm{~min}$, and centrifuged at $10000 \mathrm{~g}$ for $5 \mathrm{~min}$. The supernatant was transferred to a new micro-tube as the template DNA solution for PCR. PCR targeting VT-encoding genes was performed as follows. Primer sets EVC-1 and EVC-2 $(0.5 \mu \mathrm{l}$ each) (Takara Bio), dNTP mixture $(4 \mu \mathrm{l}), 10 \times$ Taq buffer $(5 \mu \mathrm{l})$, Takara Taq $(0.25 \mu \mathrm{l})$, template DNA solution $(2.5 \mu \mathrm{l})$ and distilled water $(37.25 \mu \mathrm{l})$ were mixed in a reaction tube. The reaction was performed at $94^{\circ} \mathrm{C}$ for $1 \mathrm{~min}$ for denaturing, at $55^{\circ} \mathrm{C}$ for $1 \mathrm{~min}$ for annealing and at $72^{\circ} \mathrm{C}$ for $1 \mathrm{~min}$ for extension using a thermal cycler (ABI7000, Applied BioSystems). After 35 cycles of the reaction, followed by heating to $72^{\circ} \mathrm{C}$ for $10 \mathrm{~min}$, the PCR products were subjected to electrophoresis in $3 \%$ agarose gel. After staining with ethidium bromide, the PCR product (171 bp) was detected under UV light.

Recovery of VT-producing $E$. coli from food inoculated with the pathogens. For inoculation, serogroups O157 (no. 157-212) and O26 (no. BFR 26015) of VT-producing E. coli were cultured in TSB at $37^{\circ} \mathrm{C}$ for $18 \mathrm{~h}$. Cultures were diluted in PBS to a $10^{-6}$ dilution, and $0.1 \mathrm{ml}$ was inoculated into each $25 \mathrm{~g}$ of ground beef and radish sprouts. The food samples were homogenized in $225 \mathrm{ml}$ modified EC including novobiocin $(\mathrm{mEC}+\mathrm{n})$ broth as an effective enrichment broth for serogroups O157 and O26 (Hara-Kudo et al., 1999, 2000; Okrend et al., 1990) with a Stomacher (model 400; AJ Seward) prior to incubation, and then incubated statically at $42^{\circ} \mathrm{C}$ for $18 \mathrm{~h}$.

The cultures of food inoculated with serogroup O157 were plated onto each of two plates of sorbitol MacConkey agar (Oxoid) supplemented with cefixime $\left(0.05 \mathrm{mg} \mathrm{l}^{-1}\right)$ and potassium tellurite $\left(2.5 \mathrm{mg} \mathrm{l}^{-1}\right)$ (CTSMAC) and CHROMagar O157 (CHROMagar) directly, or after immunomagnetic separation (IMS) performed according to the manufacturer's instructions with Dynabeads anti-E. coli O157 (Dynal). At least three colonies suspected to be $\mathrm{O} 157$ were tested for agglutination using an E. coli O157: H7 UNI latex kit (Unipath Oxoid). Acid production from lactose, acid non-production from cellobiose and non-fluorescence under UV light were observed in cellobioselactose-indole- $\beta$-D-glucuronidase (CLIG) agar (Kyokuto).

The cultures of food inoculated with serogroup O26 were plated onto each of two plates of rhamnose MacConkey agar (MacConkey agar with lactose replaced by rhamnose) (Hiramatsu et al., 2002) supplemented with cefixime $\left(0.05 \mathrm{mg} \mathrm{l}^{-1}\right)$ and potassium tellurite (2.5 $\mathrm{mg}^{-1}$ ) (CT-RMAC) and Rx ViO26 medium (Eiken Chemical) directly, or after IMS performed according to the manufacturer's instructions using immunomagnetic beads coated with anti-O26 antibody (Denka Seiken). At least three colonies suspected to be O26 were tested for agglutination using the E. coli O26 antiserum (Denka Seiken).

For PCR assay, $0.1 \mathrm{ml} \mathrm{mEC}+\mathrm{n}$ culture was transferred to a tube and centrifuged at $10000 \mathrm{~g}$ for $10 \mathrm{~min}$. After removing the supernatant, $0.1 \mathrm{ml}$ sterilized distilled water was added to the tube and the mixture was heated at $95^{\circ} \mathrm{C}$ for $5 \mathrm{~min}$. After centrifuging at $10000 \mathrm{~g}$ for $10 \mathrm{~min}$, the supernatant was used as template for the PCR described above.

For the LAMP assay, $50 \mu \mathrm{l}$ culture was added to $50 \mu \mathrm{l}$ extraction solution to extract DNA, and the LAMP reaction was then carried out as described above.

Analysis of LAMP products. Using meat obtained in an inspection carried out by the local government of Saitama prefecture, 
Table 1. Specificity of the LAMP assay

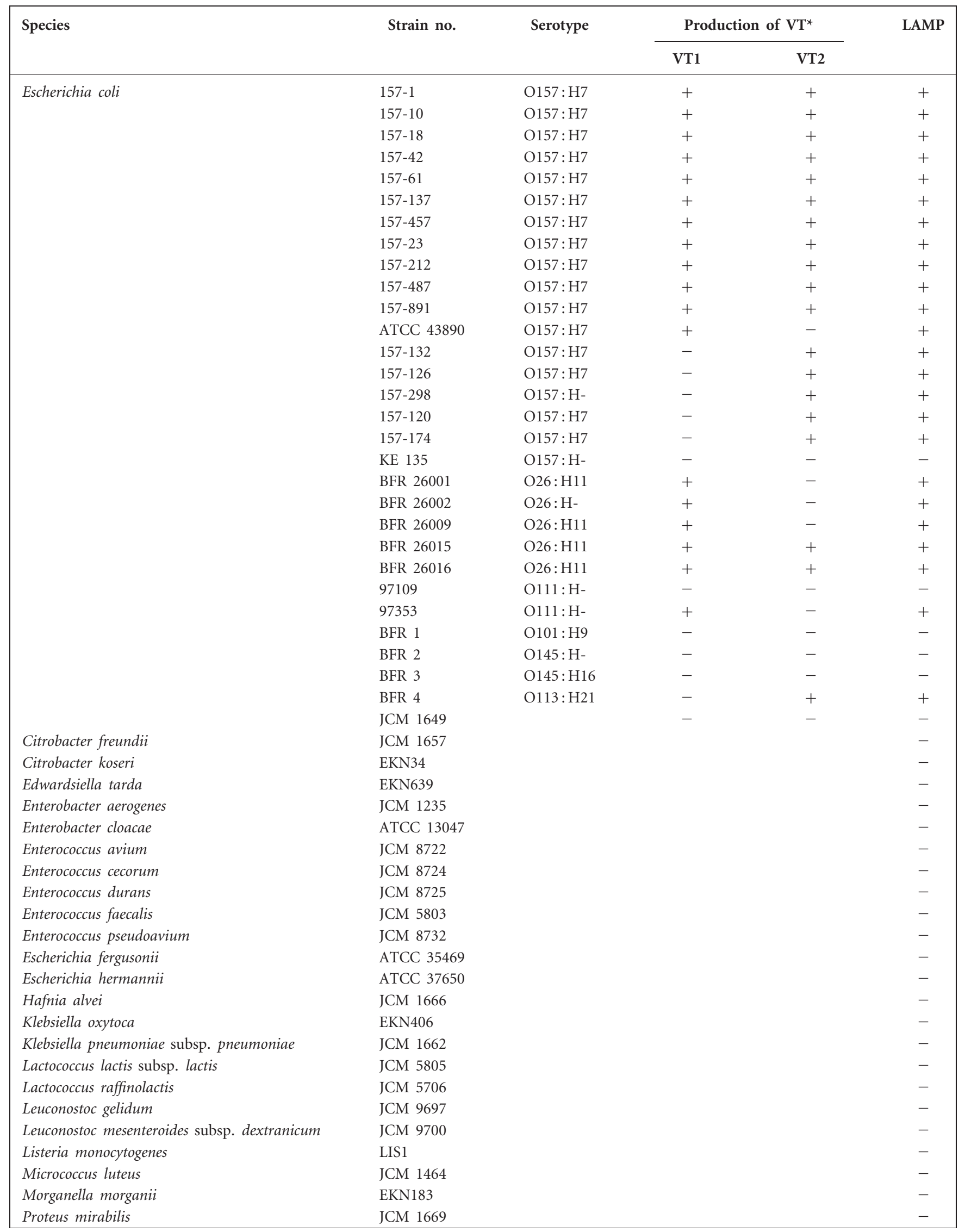


Table 1. cont.

\begin{tabular}{|c|c|c|c|c|c|}
\hline \multirow[t]{2}{*}{ Species } & \multirow[t]{2}{*}{ Strain no. } & \multirow[t]{2}{*}{ Serotype } & \multicolumn{2}{|c|}{ Production of $\mathrm{VT}^{\star}$} & \multirow[t]{2}{*}{ LAMP } \\
\hline & & & VT1 & VT2 & \\
\hline Providencia alcalifaciens & EKN182 & & & & - \\
\hline Providencia rettgeri & EKN4088 & & & & - \\
\hline Providencia stuartii & EKN4092 & & & & - \\
\hline Salmonella typhimurium & ATCC 17311 & & & & - \\
\hline Serratia marcescens & EKN233 & & & & - \\
\hline Staphylococcus aureus & ATCC 25923 & & & & - \\
\hline Staphylococcus capitis subsp. capitis & JCM 2420 & & & & - \\
\hline Staphylococcus epidermidis & JCM 2414 & & & & - \\
\hline Staphylococcus xylosus & JCM 2418 & & & & - \\
\hline Streptococcus equinus & JCM 5802 & & & & - \\
\hline Streptococcus pyogenes & JCM 5674 & & & & - \\
\hline Vibrio mimicus & ATCC 33653 & & & & - \\
\hline Vibrio parahaemolyticus & ATCC 17802 & & & & - \\
\hline Vibrio vulnuficus & IFO 15645 & & & & - \\
\hline Yersinia enterocolitica & EKN823 & & & & - \\
\hline Yersinia pseudotuberculosis & YER2 & & & & - \\
\hline
\end{tabular}

*Determined by a reversed passive latex agglutination assay.

Japan, $25 \mathrm{~g}$ surface portions of beef loaf samples were incubated in $\mathrm{mEC}+\mathrm{n}$ at $42^{\circ} \mathrm{C}$ for $18 \mathrm{~h}$. The food cultures were plated onto each of two plates of CT-SMAC and CHROMagar O157 directly, or after IMS with Dynabeads anti-E. coli O157. The culture $(1 \mathrm{ml})$ was tested by the PCR and LAMP assays described above. In four samples, the VT-encoding gene was detected in the enrichment culture by LAMP assay, although VT-producing E. coli O157 was not isolated. The enrichment cultures of four purchased beef samples (samples 03-150, 03-156, 03-266 and 03-304) were analysed by LAMP assay. The LAMP products from the samples were purified using a QIAquick PCR purification kit (Qiagen) and sequenced directly with the Vt1F2Cy5 (5'-CAT TCG TTG ACT TCT TAT CTG G-3') and Vt2F2Cy5 (5'-CAC TCA CTG GTT TCA TCA TAT CTG G-3') primers for $V T 1$ and $V T 2$ using an ABI 310 genetic analyser (Applied Biosystems) with a BigDye Terminator v. 3.1 cycle sequencing kit (Applied Biosystems). The PCR amplification products were

Table 2. LAMP primers

\begin{tabular}{|ll|}
\hline Primer & \multicolumn{1}{c|}{ Sequence $\left(\mathbf{5}^{\prime} \mathbf{- 3}^{\prime} \mathbf{)}\right.$} \\
\hline VT1 & \\
FIP & GCTCTTGCCACAGACTGCACATTCGTTGACTACTTCTTATCTGG \\
BIP & CTGTGACAGCTGAAGCTTTACGCGAAATCCCCTCTGAATTTGCC \\
F3 & GCTATACCACGTTACAGCGTG \\
B3 & ACTACTCAACCTTCCCCAGTTC \\
Loop F & AGGTTCCGCTATGCGACATTAAAT \\
VT2 & \\
FIP & GCTCTTGATGCATCTCTGGTACACTCACTGGTTTCATCATATCTGG \\
BIP & CTGTCACAGCAGAAGCCTTACGGACGAAATTCTCCCTGTATCTGCC \\
F3 & CAGTTATACCACTCTGCAACGTG \\
B3 & CTGATTCGCCGCCAGTTC \\
Loop F1 & TGTATTACCACTGAACTCCATTAACG \\
Loop F2 & GGCATTTCCACTAAACTCCATTAACG \\
\hline
\end{tabular}



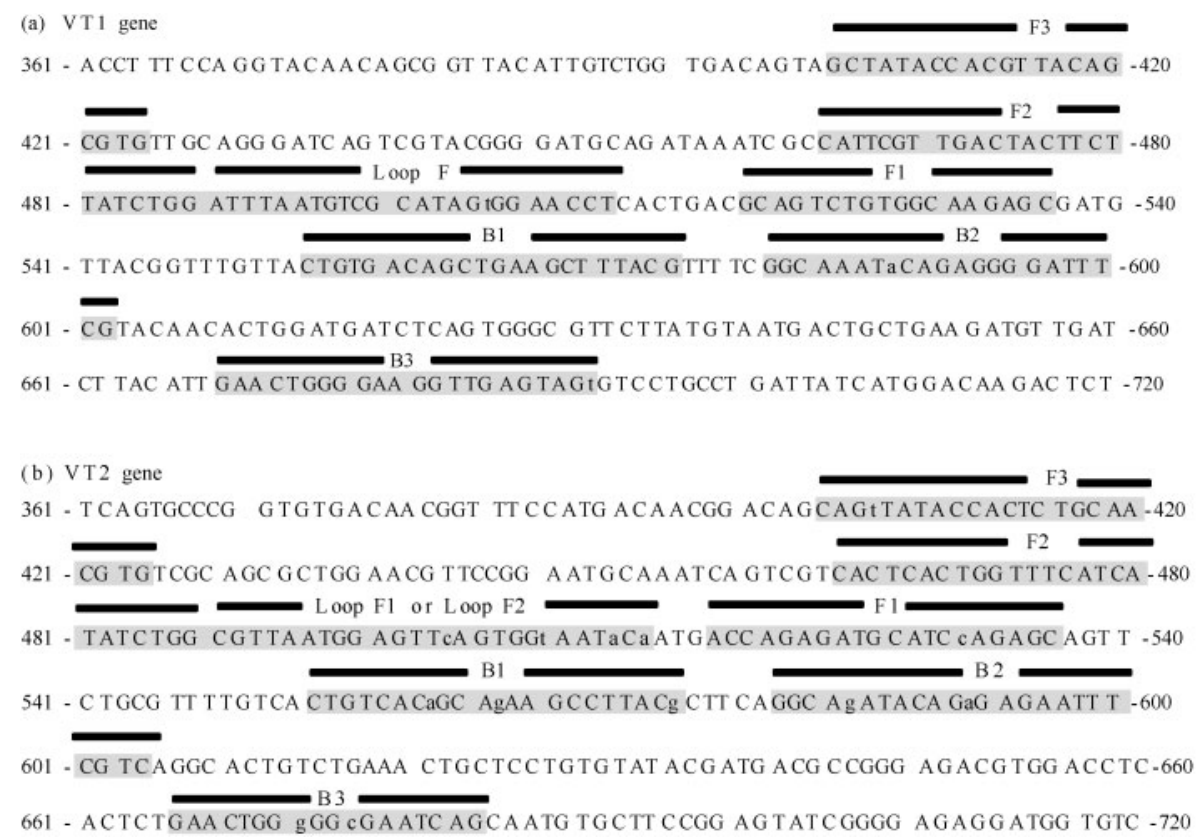

Fig. 1. Nucleotide sequences of targets for primers in the LAMP assay of VT-encoding gene of E. coli. (a) VT1 gene: a multiple alignment was determined by analyses of various VT1 sequences from the GenBank database (accession no. BA000007). (b) VT2 gene: a multiple alignment was determined by analyses of various VT2 sequences from the GenBank database (accession no. AE005174). Small letters indicate variant bases.

purified using a Montage PCR centrifugal filter device (Millipore) according to the manufacturer's instructions. The purified DNA was sequenced using an ABI310 Genetic Analyser (Applied Biosystems) with a Big Dye Terminator v3.1 cycle sequencing kit (Applied Biosystems).

Aliquots $1 \mu \mathrm{LAMP}$ products were electrophoresed in $2 \%$ agarose gel. After staining with ethidium bromide, the products were detected under UV light.

\section{RESULTS}

\section{Specificity of the LAMP assay}

Twenty-four strains of VT-producing E. coli, including either VT1- or VT2-producing E. coli or both were positive in the LAMP assay (Table 1). The serogroups were O157, O26, O111 and O145, and the serogroup did not affect the assay. Six strains of non-VT-producing E. coli, including serogroup O157, were negative in the assay. Additionally, 46 species of non-VT-producing bacteria other than E. coli were not detected.

\section{Sensitivity of the LAMP assay}

The sensitivities of the LAMP and PCR assays were tested on five strains of VT-producing E. coli at various cell densities. In the LAMP assay, all strains were detected in the $10^{-6}$ dilution (0.7-2.2 cells per test tube) (Table 3$)$. In the PCR assay, $10^{-6}$ dilutions of all strains, $10^{-5}$ dilutions of two strains and $10^{-4}$ dilutions of one strain were negative, even though they had been positive in the LAMP assay. The sensitivity of the LAMP assay was higher than that of the PCR assay for all strains tested in the present study.

\section{Recovery of VT-producing $E$. coli from food samples inoculated with the pathogen}

The inoculation levels of serogroups O157 and O26 were 8.9 and 5.9 c.f.u. per $25 \mathrm{~g}$ of ground beef, and 36.8 and 20.8 c.f.u. per 25 g of radish sprouts, respectively (Table 4).

In the ground beef samples, serogroup $\mathrm{O} 157$ was detected perfectly by all methods (Table 4). Serogroup O26 was also perfectly detected by the PCR and LAMP assays, and the IMS culture method. However, the culture method with direct plating failed to detect serogroup $\mathrm{O} 26$ in one of ten samples. In the radish sprout samples, the PCR and LAMP assays, and the culture method using plating onto CTSMAC, were successful in detecting serogroup O157 in all samples (Table 4). However, the detection ratio of plating onto CHROMagar O157 was less than that of plating onto CT-SMAC. Serogroup O26 was detected in nine of ten samples using the LAMP assay and culture with IMS, and in five of ten samples with PCR assay.

\section{Analysis of LAMP products of naturally contaminated beef samples}

Fig. 2 shows the results of the LAMP assay by three detection methods of LAMP products in four samples of beef culture and a strain culture. The cultures of the samples, but not that 
of the negative control, showed an increase in turbidity, which occurred over time (Fig. 2a). Visible turbidity was detected in the test tube (Fig. 2b). The amplicons in the tubes were analysed by agarose gel electrophoresis, and the ladder patterns of four samples showed specific amplification of the target sequence (Fig. 2c). Additionally, the LAMP products were analysed by sequencing. In the LAMP products for the VT1 gene, sequences from a part of the F1 region to a part of the $\mathrm{B} 1$ region were mostly homologous to the expected sequences (Fig. 3a). In the LAMP products for the VT2 gene, sequences from a part of the F1 region to a part of B2 were also mostly homologous to the expected sequences (Fig. 3b).

\section{DISCUSSION}

The specificity of LAMP was confirmed for VT1- and VT2producing $E$. coli of various serogroups (Table 2 ). In the present study, a loop F primer designed for VT2 contained two types. Six strains of VT2- but not VT1-producing E. coli showed a positive reaction. To confirm the sensitivity of LAMP, serogroups O157, O26 and O111, as three predominant serogroups in many countries including Japan (National Institute of Infectious Diseases \& Infectious Diseases Control Division, Ministry of Health and Welfare of Japan, 2005), were tested at various concentrations. The minimum dilution for the detection of five strains of three serogroups was $10^{-6}$. However, the concentrations of the E. coli cells were different among strains. These results demonstrate that the detection limit of the LAMP assay is between 0.7 and 2.2 cells per test tube (Table 3). The E. coli concentration of the sample was 140-440 cells $\mathrm{ml}^{-1}$. Because the contamination level of VTproducing E. coli in food is usually low, enrichment is necessary to detect it. After enrichment, the population of VT-producing E. coli should reach the minimum level detectable by the LAMP assay. In the detection of VTproducing E. coli by PCR, the PCR sensitivity found in the present study was similar (Table 3 ) to that obtained in previous studies (10-17 cells per test tube) (Kawasaki et al., 2005; Read et al., 1992), though the conditions of the PCR assay differed to some extent. Because the DNA extraction conditions were different between the PCR and LAMP assays, these conditions might affect the sensitivity. In an elementary experiment, the sensitivity of PCR assay using DNA extracted by heat treatment at $100{ }^{\circ} \mathrm{C}$ for 5 min with alkaline extraction solution and at $95^{\circ} \mathrm{C}$ for $5 \mathrm{~min}$ without extraction solution was compared. There was no difference in a test for cells without food culture or with sprouts culture.

Thus, in comparison with other assays, it was suggested that the LAMP assay is more sensitive because the amplification of the target gene using LAMP is faster and greater in yield.

(a)

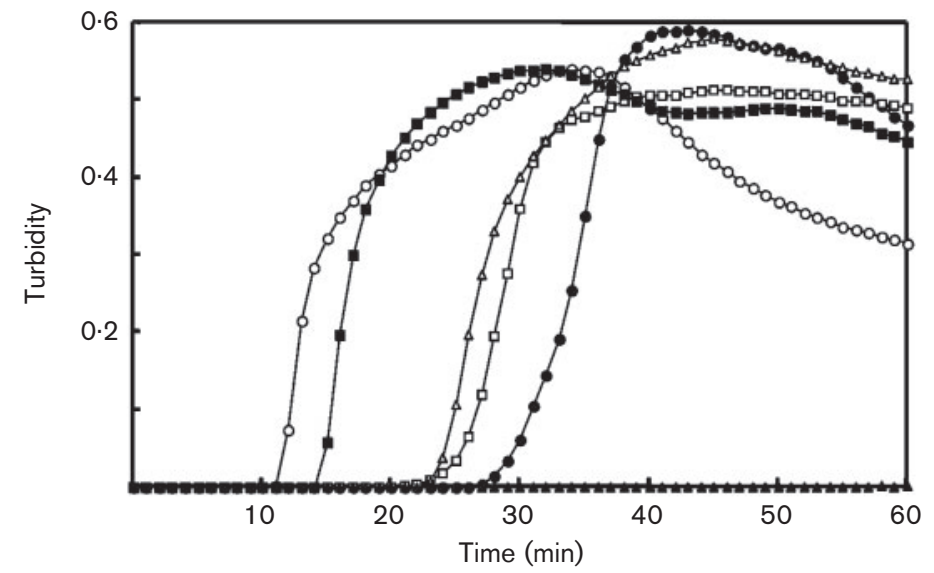

(b)

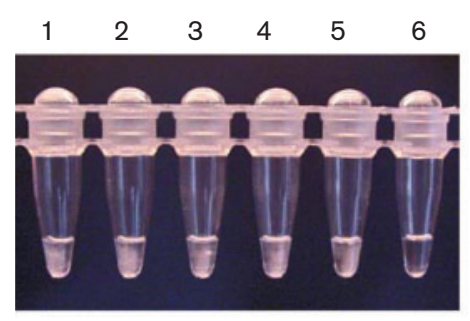

(c)

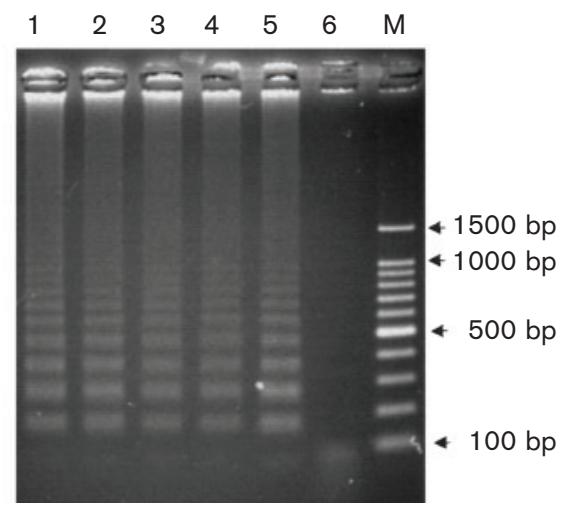

Fig. 2. The detection of VT-producing $E$. coli in naturally contaminated beef samples by turbidity and agarose electrophoresis in the LAMP assay. (a) Enterohaemorrhagic E. coli (EHEC) detection by real-time turbidity at $650 \mathrm{~nm}$. Cell suspension of strain no. 157-212 ( $\bigcirc)$ was used as a positive control, the samples were cultures in $\mathrm{mEC}+\mathrm{n}$ of naturally contaminated beef samples 03$150(\bullet), 03-156(\square), 03-266(\square)$ and 03$304(\triangle)$, a negative control was used $(\mathbf{\Delta})$. (b) Visual EHEC detection by observation of turbidity: tube 1, strain no. 157-212; tube 2, beef sample 03-150; tube 3 , beef sample 03-156; tube 4, beef sample 03-266; tube 5 , beef sample 03-304; tube 6, negative control. (c) EHEC detection by agarose gel electrophoresis: lane 1, strain no. 157-212; lane 2, beef sample 03-150; lane 3, beef sample 03-156; lane 4, beef sample 03266; lane 5, beef sample 03-304; lane 6, negative control; lane $\mathrm{M}, 100 \mathrm{bp}$ ladder size markers (Takara). 
(a) VT1 gene

Strain No. 157-212

Beef sample No. 03-150 Beef sample No. 03-156 Beef sample No. 03-266 Beef sample No. 03-304

(b) VT2 gene

Strain No. 157-212

Beef sample No. 03-150 Beef sample No. 03-156 Beef sample No. 03-266 Beef sample No. 03-304

Strain No. 157-212 Beef sample No, 03-150 Beef sample No. 03-156 Beef sample No. 03-266 Beef sample No. 03-304
$\mathrm{F} 1 \longrightarrow$

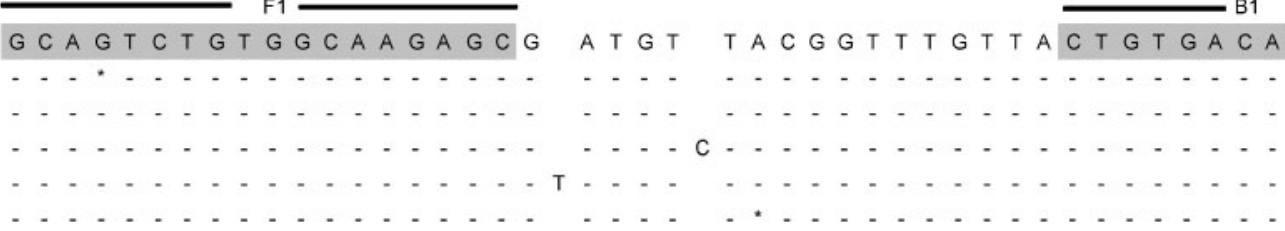

F1

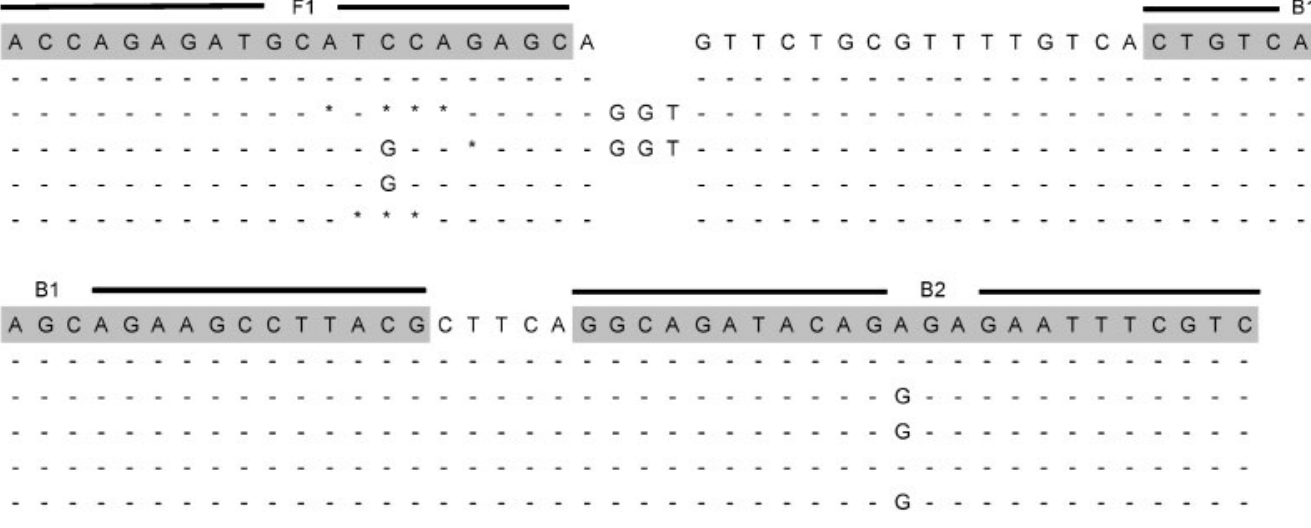

Fig. 3. Analysis of the sequences of products of LAMP for VT-producing $E$. coli in naturally contaminated beef samples: (a) VT1 gene, (b) VT2 gene. The cultures of four samples and a control strain (no. 157-212) were tested. Identical (-) and missing $\left(^{\star}\right)$ nucleotides compared with the expected sequences are indicated.

To confirm the LAMP amplification of the target, an examination of the ladder patterns by agarose gel electrophoresis is useful. Furthermore, the sequences of the product are useful to confirm the PCR amplification of the target. Notomi et al. (2000) confirmed the structures of the LAMP amplified products for HBs regions of hepatitis virus $B$ by cloning and sequencing. The results of the present analysis show that the sequences of LAMP products from naturally contaminated beef samples coincide well with the expected sequences.

Table 3. Sensitivity of the LAMP assay in enterohaemorrhagic E. coli

\begin{tabular}{|c|c|c|c|c|c|c|c|}
\hline \multirow[t]{2}{*}{ Strain no. } & \multirow[t]{2}{*}{ Serogroup } & \multirow[t]{2}{*}{ VT } & & \multicolumn{4}{|c|}{ Dilution of cultures for assay } \\
\hline & & & & $10^{-3}$ & $10^{-4}$ & $10^{-5}$ & $10^{-6}$ \\
\hline $157-891$ & $\mathrm{O} 157$ & VT1 and VT2 & $\begin{array}{l}\text { Cell number in test tube } \\
\text { LAMP assay }\end{array}$ & 1113 & 111.3 & 11.1 & 1.1 \\
\hline & & & PCR assay & & & - & - \\
\hline ATCC 43890 & O157 & VT1 & $\begin{array}{l}\text { Cell number in test tube } \\
\text { LAMP assay }\end{array}$ & 800 & 80 & 8.0 & 0.8 \\
\hline & & & PCR assay & & & - & - \\
\hline $157-120$ & O157 & VT2 & $\begin{array}{l}\text { Cell number in test tube } \\
\text { LAMP assay } \\
\text { PCR assay }\end{array}$ & 1338 & 133.8 & 13.4 & $\begin{array}{l}1.3 \\
-\end{array}$ \\
\hline BFR 26015 & $\mathrm{O} 26$ & VT1 and VT2 & $\begin{array}{l}\text { Cell number in test tube } \\
\text { LAMP assay } \\
\text { PCR assay }\end{array}$ & 675 & 67.5 & 6.8 & $\begin{array}{r}0.7 \\
-\end{array}$ \\
\hline 97353 & O111 & VT1 & $\begin{array}{l}\text { Cell number in test tube } \\
\text { LAMP assay } \\
\text { PCR assay }\end{array}$ & 2225 & 222.5 & 22.3 & $\begin{array}{r}2.2 \\
-\end{array}$ \\
\hline
\end{tabular}


Table 4. Recovery of enterohaemorrhagic E. coli O157 and O26 by the culture method, and detection by PCR and LAMP assays

Ten samples were tested in each inoculation experiment. Five samples of each food were tested to confirm no natural contamination with enterohaemorrhagic E. coli $\mathrm{O} 157$ or O26. Inoculation level (c.f.u. per 25 g): 8.9 of O157: H7 and 5.9 of O26 in ground beef; 36.8 of $\mathrm{O} 157: \mathrm{H} 7$ and 20.8 of $\mathrm{O} 26$ in radish sprouts.

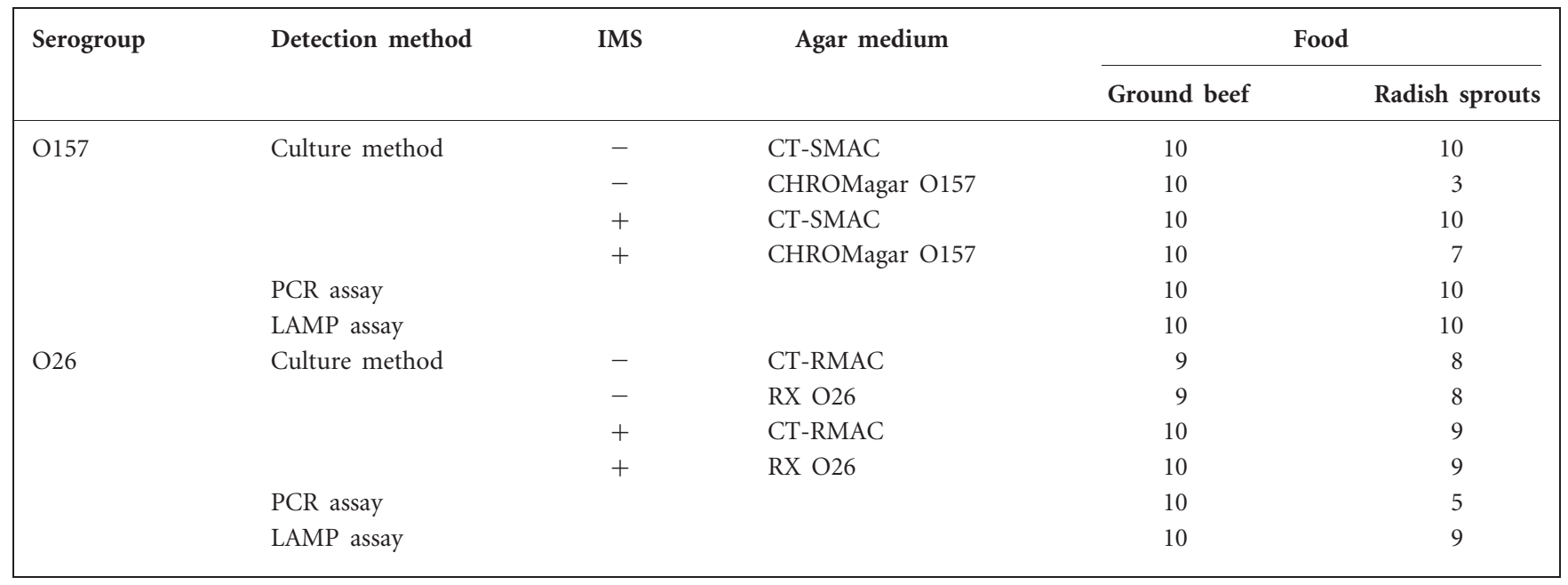

VT-producing E. coli is known to include many serogroups (Bettelheim, 2000) and new serogroups might be added in the future. In fact, $1 \%$ of isolates of VT-producing E. coli in Japan are currently untypable using commercially available antisera (National Institute of Infectious Diseases \& Infectious Diseases Control Division, Ministry of Health and Welfare of Japan, 2004). Methods of detecting VTproducing E. coli were developed using culture and molecular techniques. The isolation of VT-producing $E$. coli is essential for the typing of strains and identification of the cause of food-borne infections. Effective media to isolate serogroup $\mathrm{O} 157$ are available worldwide, but there are few effective media for other VT-producing E. coli (Bettelheim, 1995; Hara-Kudo et al., 2002).

The present study demonstrates that the LAMP assay is effective in detecting VT-producing E. coli rapidly and with high sensitivity; we thus recommend it as an effective and time-saving method. Firstly the presence of the VT-encoding gene is tested in enrichment culture with LAMP assays. Immediately after the result is obtained, VT-encoding gene positive culture is plated onto agar media for serogroup O157 and other serogroups of E. coli. In addition, IMS using beads coated with $\mathrm{O} 157$ and other $\mathrm{O}$ antibodies improves the isolation of VT-producing E. coli from VT-encoding gene positive culture. After overnight incubation, colonies suspected to be serogroup O157 and other serogroups of E. coli on each medium are tested for the VT-encoding gene using the LAMP assay. Finally, the serogroups of all VTencoding gene positive colonies are determined. This procedure improves public health, including food safety.

\section{ACKNOWLEDGEMENTS}

This study was supported in part by a grant from the Japan Health Sciences Foundation and a Health Sciences Research Grant from the Ministry of Health, Labour and Welfare, Japan.

\section{REFERENCES}

Beige, J., Lokies, J., Schaberg, T., Finckh, U., Fischer, M., Mauch, H., Lode, H., Kohler, B. \& Rolfs, A. (1995). Clinical evaluation of a Mycobacterium tuberculosis PCR assay. J Clin Microbiol 33, 90-95.

Bennett, A. R., MacPhee, S. \& Betts, R. P. (1996). The isolation and detection of Escherichia coli $\mathrm{O} 157$ by use of immunomagnetic separation and immunoassay procedures. Lett Appl Microbiol 22, 237-243.

Bettelheim, K. A. (1995). Identification of enterohaemorrhagic Escherichia coli by means of their production of enterohaemolysin. J Appl Bacteriol 79, 178-180.

Bettelheim, K. A. (2000). Role of non-O157 VTEC. Symp Ser Soc Appl Microbiol 88, 38S-50S.

Chapman, P. A., Ellin, M. \& Ashton, R. (2001). A comparison of immunomagnetic separation and culture, Reveal ${ }^{\mathrm{TM}}$ and VIP ${ }^{\mathrm{TM}}$ for the detection of E. coli $\mathrm{O} 157$ in enrichment cultures of naturallycontaminated raw beef, lamb and mixed meat products. Lett Appl Microbiol 32, 171-175.

Hara-Kudo, Y., Onoue, Y., Konuma, H., Nakagawa, H. \& Kumagai, S. (1999). Comparison of enrichment procedures for isolation of Escherichia coli O157:H7 from ground beef and radish sprouts. Int J Food Microbiol 50, 211-214.

Hara-Kudo, Y., Konuma, H., Nakagawa, H. \& Kumagai, S. (2000). Escherichia coli $\mathrm{O} 26$ isolation from foods using enrichment procedure and immunomagnetic separation method. Lett Appl Microbiol 30, 151-154. 
Hara-Kudo, Y., Ikedo, M., Komatsu, O., Yamamoto, S. \& Kumagai, S. (2002). Evaluation of a chromogenic agar medium for isolation of Escherichia coli O26. Food Control 13, 377-379.

Hiramatsu, R., Matsumoto, M., Miwa, Y., Suzuki, Y., Saito, M. \& Miyazaki, Y. (2002). Characterization of Shiga toxin-producing Escherichia coli O26 strains and establishment of selective isolation media for these strains. J Clin Microbiol 40, 922-925.

Ito, H., Terai, A., Kurazono, H., Takeda, Y. \& Nishibuchi, M. (1990). Cloning and nucleotide sequencing of Vero toxin 2 variant genes from Escherichia coli $\mathrm{O} 91: \mathrm{H} 21$ isolated from a patient with the hemolytic uremic syndrome. Microb Pathog 8, 47-60.

Ito, H., Nishibuchi, M. \& Takeda, Y. (1991). Analysis of the antigenic difference between Vero toxin 2 (VT2) and VT2 variant (VT2vh) of Verotoxin-producing Escherichia coli by a site-directed mutagenesis. FEMS Microbiol Lett 15, 27-30.

Jackson, M. P., Neill, R. J., O’Brien, A. D., Holmes, R. K. \& Newland, J. W. (1987). Nucleotide sequence analysis and comparison of the structural genes for Shiga-like toxin I and Shiga-like toxin II encoded by bacteriophages from Escherichia coli 933. FEMS Microbiol Lett 44, 109-114.

Kawasaki, S., Horikoshi, N., Okada, Y., Takeshita, K., Sameshima, T. \& Kawamoto, S. (2005). Multiplex PCR for simultaneous detection of Salmonella spp., Listeria monocytogenes, and Escherichia coli O157: H7 in meat samples. J Food Prot 68, 551-556.

Lin, Z., Yamasaki, S., Kurazono, H., Ohmura, M., Karasawa, T., Inoue, T., Sakamoto, S., Suganami, T., Takeoka, T. \& other authors (1993). Cloning and sequencing of two new Vero toxin 2 variant genes of Escherichia coli isolated from cases of human and bovine diarrhea. Microbiol Immunol 37, 451-459.

Mori, Y., Nagamine, K., Tomita, N. \& Notomi, T. (2001). Detection of loop-mediated isothermal amplification reaction by turbidity derived from magnesium pyrophosphate formation. Biochem Biophys Res Commun 289, 150-154.
Mullah, B., Livak, K., Andrus, A. \& Kenney, P. (1998). Efficient synthesis of double dye-labeled oligodeoxyribonucleotide probes and their application in a real-time PCR assay. Nucleic Acids Res 26, 1026-1031.

Nagamine, K., Watanabe, K., Ohtsuka, K., Hase, T. \& Notomi, T. (2001). Loop-mediated isothermal amplification reaction using a nondenatured template. Clin Chem 47, 1742-1743.

Nagamine, K., Kuzuhara, Y. \& Notomi, T. (2002). Isolation of single-stranded DNA from loop-mediated isothermal amplification products. Biochem Biophys Res Commun 290, 1195-1198.

National Institute of Infectious Diseases \& Infectious Diseases Control Division, Ministry of Health and Welfare of Japan (2004). Enterohemorrhagic Escherichia coli infection, as of May 2004. Infect Agents Surveillance Rep 25, 138-143 (in Japanese).

National Institute of Infectious Diseases\& Infectious Diseases Control Division, Ministry of Health and Welfare of Japan (2005). Enterohemorrhagic Escherichia coli infection, as of May 2005. Infect Agents Surveillance Rep 26, 137-138 (in Japanese).

Notomi, T., Okayama, H., Masubuchi, H., Yonekawa, T. Watanabe, K., Amino, N. \& Hase, T. (2000). Loop-mediated isothermal amplification of DNA. Nucleic Acids Res 28, E63.

Okrend, A. J. G., Rose, B. E. \& Bennett, B. (1990). A screening method for the isolation of Escherichia coli O157:H7 from ground beef. J Food Prot 53, 249-252.

Read, S. C., Clarke, R. C., Martin, A., De Grandis, S. A., Hii, J., McEwen, S. \& Gyles, C. L. (1992). Polymerase chain reaction for detection of verotoxigenic Escherichia coli isolated from animal and food sources. Mol Cell Probes 6, 153-161.

Weinstein, D. L., Jackson, M. P., Samuel, J. E., Holmes, R. K. \& O'Brien, A. D. (1988). Cloning and sequencing of a Shiga-like toxin type II variant from an Escherichia coli strain responsible for edema disease of swine. J Bacteriol 170, 4223-4230. 